\title{
IN-VITRO BIOCONTROL POTENTIAL AND MECHANISM OF INHIBITION OF INDIGENOUS TRICHODERMA ISOLATES FROM SOUTHEAST SULAWESI PROVINCE OF INDONESIA AGAINST SCLEROTIUM ROLFSII
}

\author{
Gusnawaty H.S., Muhammad Taufik, Vit Neru Satrah, Novita Pramahsari Putri, La Ode Santiaji Bande, Asniah \\ Mariadi \\ Department of Plant Protection, Faculty of Agriculture, Halu Oleo University, Kendari, Indonesia.
}

\section{A R T I C L E I N F O}

\section{Article history}

Received: $13^{\text {th }}$ September, 2020

Revised: $7^{\text {th }}$ November, 2020

Accepted: $27^{\text {th }}$ December, 2020

\section{Keywords}

Inhibitionon

Sclerotium rolfsii

Trichoderma

Antibiosis

Mycoprasitism

\begin{abstract}
A B S T RACT
Sclerotium rolfsii is an important plant pathogen and causes disease in some cultivated plants especially in Southeast Sulawesi. S. rolfsii is mainly controlled by using synthetic fungicides which are hazardous to human, livestock and environment. In the present study, eleven species of Trichoderma, indigenous to Southeast Sulawesi, were tested for their in vitro efficacy against $S$. rolfsii to replace deleterious fungicides. The analysis of variance showed significant results of the indigenous Trichoderma spp. against $S$. rolfsii. in in vitro test. All the Trichoderma isolates inhibited the growth of the test fungus differently. After three days of inoculation, ST1 treatment showed the highest inhibitory ability by $55.56 \%$ but was not significantly different from the inhibitory abilities of ST2, ST3, ST5, ST6, ST7, ST9, ST10, and ST11 treatments. The treatment ST4 and ST8 gave inhibitory abilities by $25.22 \%$ and $26.11 \%$ respectively. Furthermore, the data after 4, 5, 6 and 7 days after inoculation were also significant. The ST1 (DKT isolate) treatment gave the maximum inhibition of the test fungus after all the time intervals of seven days. On the other hand, ST8 (LKP isolate) treatment gave the lowest inhibitory ability. DKT isolate of indigenous Trichoderma had the highest inhibitory ability reaching to $55.56 \%$ on third days of observation while LKP isolate had the lowest inhibitory ability of $16.67 \%$ and then decreased subsequently. the antagonistic mechanisms of Trichoderma isolates were space and nutrition competition, antibiosis, and mycoparasitism. These results showed that Trichoderma indigenous to Southeast Sulawesi had better in vitro inhibitory ability to control $S$. rolfsii by the abovementioned mechanisms.
\end{abstract}

Corresponding Author: Gusnawaty HS

Email: gusnawatyhs@gmail.com

(C) 2020 EScience Press. All rights reserved.

\section{INTRODUCTION}

Various studies report that Trichoderma can control various types of plant pathogens such as Phytophthora infestans that causes late blight of potato and tomato and some other cultivated plants (Purwantisari and Hastuti,
2009), Pythium sp., the cause of damping-off disease in durian seedlings (Octriana, 2016), and Sclerotium rolfsii causing damping-off in crops and vegetables (Supriati et al., 2010). According to the research of Prayudi et al. (2005), Trichoderma isolates indigenous to South 
Kalimantan had a better ability to control rice leaf midrib blight disease in the tidal land area of South Kalimantan compared to Trichoderma sp. indigenous to Yogyakarta. This proved that local isolates had the best potential to suppress pathogens in their home regions.

In earlier study, differences in the morphological characteristics of eleven isolates of Trichoderma spp. indigenous to Southeast Sulawesi have been determined. The isolates differed on the basis of different morphological characteristics. These 11 isolates of Trichoderma spp. comprised T. hamantum, T. koningii, T. harzianum, T. polysporum and T. aureoviride (Gusnawaty et al., 2014a). The biocontrol potential of these Trichoderma species was then tested against Phytophthora capsici (Gusnawaty et al., 2013), Colletotrichum sp. (Gusnawaty et al., 2014b) and Fusarium oxysporum (Gusnawaty et al., 2015) as currently, the disease management in agriculture is more focused on eco-friendly management and the use of Trichoderma spp. could be effective in this regard. Trichoderma has the ability as a mycoparasite which is antagonistic to some plant fungal pathogens including Sclerotium rolfsii. It can increase plant growth and can be used as organic fertilizer or bio-fungicide (Gusnawaty et al., 2020a).

Sclerotium rolfsii is an important plant pathogen and causes disease in some cultivated plants especially in Southeast Sulawesi. Symptoms caused by $S$. rolfsii include brownish spots around the base of the stem, leaves turn yellow, wither on the branches and eventually die. Furthermore, the pathogen spreads to all parts of the plant and causes rot on the plant (Gusnawaty et al., 2020b; Gusnawaty et al., 2014b). Ferreira and Boley (1992) reported that S. rolfsii has broad host range of plants such as eggplant, tomatoes, bananas, mangoes, cabbage, carrots, lettuce, corn, sweet potato, taro, sugarcane, cotton, coffee, and ginger. This pathogen can cause death when plants are still young or in the vegetative phase. The management of the pathogen is difficult because it is soilborne and can survive in the soil by forming sclerotia.

Currently, $S$. rolfsii is mainly controlled by using synthetic fungicides and resistant cultivars. Although, synthetic fungicides are instantly effective against plant pathogens but their continuous application is detrimental to humans, livestock and environment. Furthermore, continuous use of the same fungicides for the same pathogen results in the development of resistant strains of the pathogens (Iqbal et al., 2014). As there are no resistant cultivars against $S$. rolfsii and the use of fungicides is expensive and dangerous, therefore, use of biocontrol agents could be one of the practicable and best substitutes to decrease yield losses by the pathogen. Among various fungal biocontrol agents, Trichoderma species have been most widely studied against different phytopathogens (Iqbal and Mukhtar, 2014, 2020a, 2020b; Mukhtar, 2018). For the aforementioned reasons, the present study was conducted with the aim to screen eleven species of Trichoderma, indigenous to Southeast Sulawesi, for their in vitro efficacy against $S$. rolfsii.

\section{MATERIALS AND METHODS}

The present research was carried out in the Laboratory of Plant Protection, Department of Plant Protection, Faculty of Agriculture, Halu Oleo University, Indonesia. Eleven Trichoderma isolates were used in this study. These isolates were isolated from the rhizosphere of various types of cultivated plants in Southeast Sulawesi (Table 1). The isolates were grown on PDA media and incubated for seven days.

In vitro inhibition test was carried out on PDA media using dual culture method (Iqbal et al., 2014). Seven days old cultures of all the indigenous isolates of Trichoderma and that of $S$. rolfsii were grown on sterile PDA media. Individual purified cultures of Trichoderma isolates and the pathogenic fungus were placed at equidistances on $9 \mathrm{~mm}$ PDA petri plates. The petri plates inoculated with the antagonists and pathogenic fungus were incubated in dark at $25 \pm 1^{\circ} \mathrm{C}$ for 7 days. Each treatment was repeated three times.

Observations were carried out for seven days by measuring the pathogen growth radius toward the edge of the Petri dish (R1) and the pathogen growth radius toward the indigenous Trichoderma (R2). Furthermore, the data obtained were used to calculate the inhibition (DH) of $S$. rolfsii by each indigenous isolate of Trichoderma. The inhibition of the pathogenic fungus by the Trichoderma spp. was calculated by the formula described by Sudanta et al. (2011).

Where:

$$
D H(\%)=\frac{R 1-R 2}{\mathrm{R} 1} \times 100
$$

$R_{1}$ : the radius of growth of pathogenic fungi (S. rolfsii) towards the edge of the Petri dish (away from indigenous Trichoderma)

$R_{2}$ : the radius of growth of pathogen (S.rolfsii) in the 
direction of indigenous Trichoderma.

The Completely Randomized Design was used in the study. All the data were analyzed using analysis of variance (ANOVA). In case of significant results, the meanings were separated by Duncans Multiple Range Test (DMRT) at $\alpha: 0.05$, while the inhibition mechanism was analyzed descriptively based on visible appearance or what happened to the $S$. rolfsii colony.

Table 1. The Description of isolates of Trichoderma spp. indigenous to Southeast Sulawesi.

\begin{tabular}{cllllll}
\hline \multirow{2}{*}{ No. } & \multirow{2}{*}{ Isolate } & \multirow{2}{*}{ Trichoderma spp. } & \multicolumn{3}{c}{ Origin of Soil Sample } & Type of \\
\cline { 4 - 5 } & & & Village & Sub-district & District & vegetation \\
\hline 1 & DKT & T. koningii & Duriasi & Wonggeduku & Konawe & Cucumber \\
2 & BPS & T. harzianum & Baruga & Watubangga & Konawe & Paddy \\
3 & LKA & T. aureoviride & Leleuta & Ngapa & North Kolaka & Cacao \\
4 & ASL & T. hamantum & Asunde & Besulutu & Konawe & Pepper \\
5 & LTB & T. aureoviride & Lamooso & Angata & South Konawe & Cane \\
6 & APS & T. koningii & Ameroro & Landono & South Konawe & Bitter melon \\
7 & LPS & T. harzianum & Loea & Tirawuta & Kolaka & Paddy \\
8 & LKP & T. polysporum & Loea & Tirawuta & Kolaka & Yardlong bean \\
9 & DPA & T. koningii & Duriasi & Wonggeduku & Konawe & Bitter melon \\
10 & LKO & T. harzianum & Lapai & Ngapa & North Kolaka & Cacao \\
11 & DKP & T. koningii & Duriasi & Wonggeduku & Konawe & Yardlong bean \\
\hline
\end{tabular}

\section{RESULTS AND DISCUSSION}

The analysis of variance showed significant results of the indigenous Trichoderma spp. against $S$. rolfsii. in in vitro test. All the Trichoderma isolates inhibited the growth of the test fungus differently. After three days of inoculation, ST1 treatment showed the highest inhibitory ability by $55.56 \%$ but was not significantly different from the inhibitory abilities of ST2, ST3, ST5, ST6, ST7, ST9, ST10, and ST11 treatments. The treatment ST4 and ST8 gave inhibitory abilities by $25.22 \%$ and $26.11 \%$ respectively. Furthermore, the data after 4, 5, 6 and 7 days after inoculation were also significant. The ST1 (DKT isolate) treatment gave the maximum inhibition of the test fungus after all the time intervals of seven days. On the other hand, ST8 (LKP isolate) treatment gave the lowest inhibitory ability (Table 2).

DKT isolate of indigenous Trichoderma had the highest inhibitory ability reaching to $55.56 \%$ on third days of observation while LKP isolate had the lowest inhibitory ability of $16.67 \%$ and then decreased subsequently. These results showed that Trichoderma indigenous to Southeast Sulawesi had better in vitro inhibitory ability compared to the results of Supriati et al. (2010) who reported that Trichoderma isolates which were tested in vitro could only inhibit the growth of $S$. rolfsii by $51 \%$.

The differences in inhibitory ability was thought to be due to differences in the character of each indigenous Trichoderma isolate which closely related to the growth rate on the media and its inhibitory mechanism. The results of the study by Gusnawaty et al. (2014a) showed that there were differences in morphological characters both macroscopically and microscopically in the 11 isolates of Trichoderma indigenous to Southeast Sulawesi. Similarly, according to Ismail and Tenrirawe (2010), the high growth rate of Trichoderma spp. was one important factor that determines the potential of Trichoderma spp. as a biological agent.

Based on observations, it could be seen that the mechanism of inhibition of Trichoderma isolates indigenous to Southeast Sulawesi against $S$. rolfsii on dual culture was due to space competition, mycoparasitism, and antibiosis. Winarsih and Syafrudindan (2001) reported that there were three antagonistic mechanisms of Trichoderma namely (1) space and nutrition competition, (2) antibiosis, and (3) hyphal/mycoparasitic system of interactions. Berlian et al. (2013) also stated that the mechanism of control with biological agents against plant pathogenic fungi, in general, was competition for growth sites and nutrition, antibiosis, and parasitism. According to Khokhar et al. (2012), the mechanism of parasitism was an antagonistic mechanism that could directly suppress the growth of pathogens. The mechanism of space or nutrition competition and parasitism was seen in the treatments of ST1, ST2, ST5, ST6, ST7, ST9, ST10, and ST11 (Figure 1). This was indicated by the growth of 
indigenous isolates of Trichoderma which occupied the medium even up to the surface of $S$. rolfsii colonies so that the growth of $S$. rolfsii colonies was retarded and finally stopped. It was different from ST3 treatment (Figure 2) which only showed the growth of Trichoderma isolates that filled the solid media but did not grow to meet the surface of $S$. rolfsii colonies so that it was only possible for the mechanism of space or nutrition competition. According to Sunarwati and Yoza (2010), the difference in the size of the fungus colonies in the media indicated that there was a mechanism of space and nutrition competition. The existence of this ability caused pathogens to not get space for their place of life and did not get nutrients as an energy source so that their growth and development was inhibited (Ropalia, 2017). The profuse growth of the colonies of biological agents showed their ability to compete with pathogens. Furthermore, according to Berlian et al. (2013), the mechanism of parasitism, hypha of Trichoderma spp. grew lengthwise, then convolved and penetrated the host fungus hyphae so that the host hyphae were vacuated, lysis and finally destroyed.

Table 2. In vitro inhibition ability of indigenous isolates of Trichoderma spp. against S. Rolfsii.

\begin{tabular}{llrrrrr}
\hline \multirow{2}{*}{ Treatment } & \multicolumn{7}{c}{ In vitro percentage inhibition ability of Trichoderma spp. isolates against S. rolfsii up to 7 days } \\
& \multicolumn{7}{c}{2} & 3 & 4 & 5 & 6 & 7 \\
\cline { 2 - 6 } & $55.56 \mathrm{a}$ & $55.56 \mathrm{a}$ & $55.56 \mathrm{a}$ & $55.56 \mathrm{a}$ & $55.56 \mathrm{a}$ & $55.56 \mathrm{a}$ \\
ST1 (DKT) & $41.67 \mathrm{ab}$ & $51.11 \mathrm{a}$ & $51.11 \mathrm{a}$ & $51.11 \mathrm{a}$ & $51.11 \mathrm{a}$ & $51.11 \mathrm{a}$ \\
ST2 (BPS) & $50.48 \mathrm{a}$ & $51.11 \mathrm{a}$ & $51.11 \mathrm{a}$ & $51.11 \mathrm{a}$ & $51.11 \mathrm{a}$ & $51.11 \mathrm{a}$ \\
ST3 (LKA) & $25.22 \mathrm{~b}$ & $31.88 \mathrm{~b}$ & $31.88 \mathrm{~b}$ & $31.88 \mathrm{~b}$ & $31.88 \mathrm{~b}$ & $31.88 \mathrm{~b}$ \\
ST4 (ASL) & $51.55 \mathrm{a}$ & $54.81 \mathrm{a}$ & $54.81 \mathrm{a}$ & $54.81 \mathrm{a}$ & $54.81 \mathrm{a}$ & $54.81 \mathrm{a}$ \\
ST5 (LTB) & $43.00 \mathrm{ab}$ & $51.39 \mathrm{a}$ & $51.39 \mathrm{a}$ & $51.39 \mathrm{a}$ & $51.39 \mathrm{a}$ & $51.39 \mathrm{a}$ \\
ST6 (APS) & $50.01 \mathrm{a}$ & $51.11 \mathrm{a}$ & $51.11 \mathrm{a}$ & $51.11 \mathrm{a}$ & $51.11 \mathrm{a}$ & $51.11 \mathrm{a}$ \\
ST7 (LPS) & $26.11 \mathrm{~b}$ & $16.67 \mathrm{c}$ & $12.22 \mathrm{c}$ & $12.22 \mathrm{c}$ & $12.22 \mathrm{c}$ & $12.22 \mathrm{c}$ \\
ST8 (LKP) & $50.15 \mathrm{a}$ & $53.12 \mathrm{a}$ & $53.12 \mathrm{a}$ & $53.12 \mathrm{a}$ & $53.12 \mathrm{a}$ & $53.12 \mathrm{a}$ \\
ST9 (DPA) & $52.24 \mathrm{a}$ & $53.89 \mathrm{a}$ & $53.89 \mathrm{a}$ & $53.89 \mathrm{a}$ & $53.89 \mathrm{a}$ & $53.89 \mathrm{a}$ \\
ST10 (LK0) & $54.44 \mathrm{a}$ & $54.44 \mathrm{a}$ & $54.44 \mathrm{a}$ & $54.44 \mathrm{a}$ & $54.44 \mathrm{a}$ & $54.44 \mathrm{a}$ \\
ST11 (DKP) & & & & &
\end{tabular}
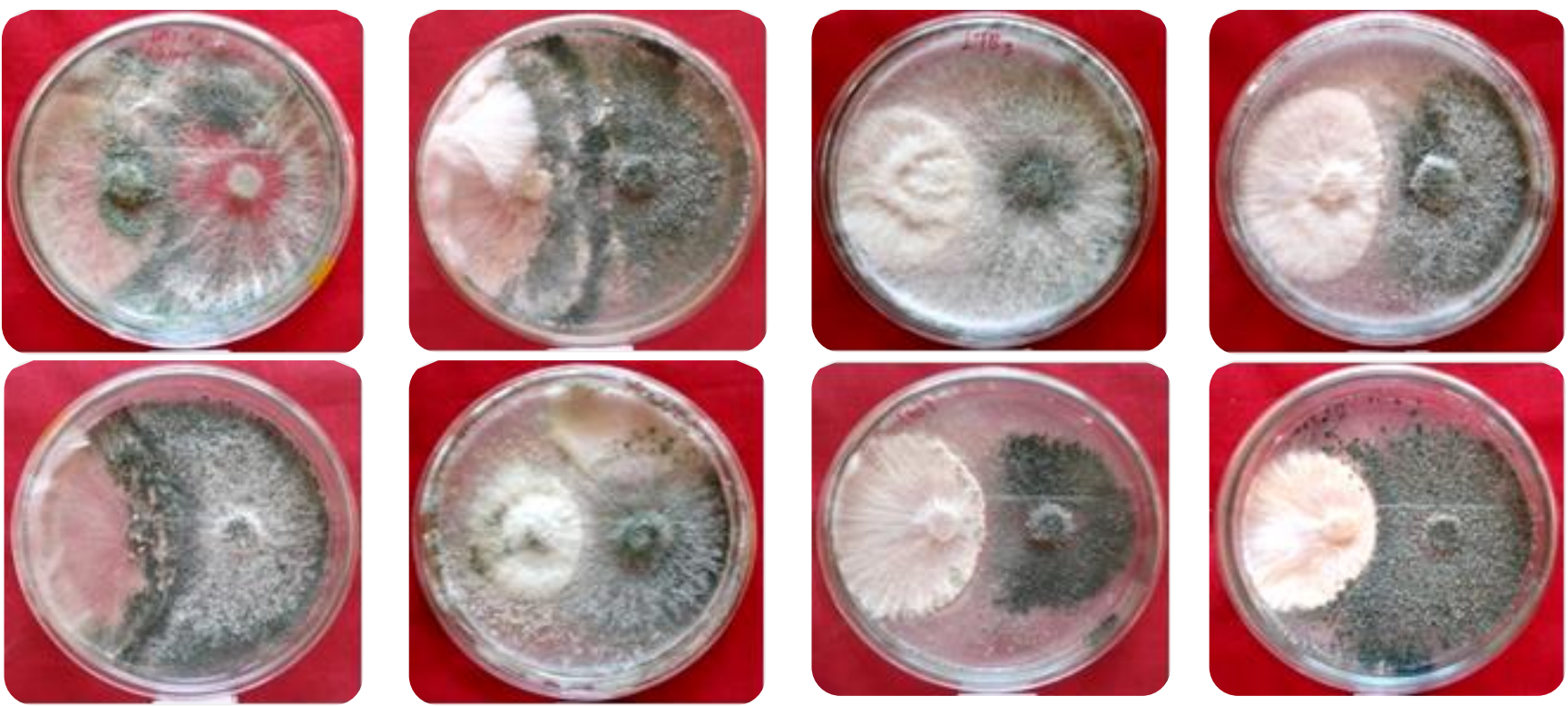

Figure 1. Mechanism of space competition and mycoparasitism shown by isolates of Trichoderma spp. against $S$. rolfsii, a: ST1 (DKT), b: ST2 (BPS), c: ST5 (LTB), d: ST6 (APS), e: ST7 (LPS), f: ST9 (DPA), g: ST10 (LKO) and h: ST11 (DKP). 


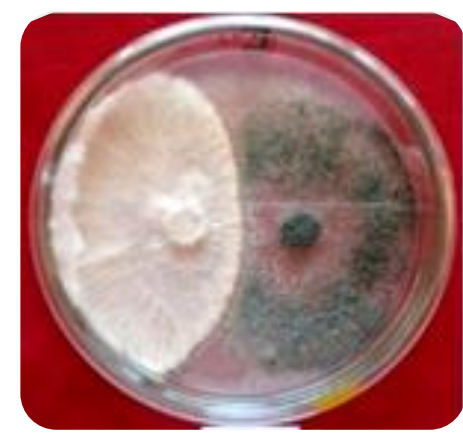

Figure 2. Mechanisms of inhibition by Trichoderma indigenous isolate LKA against $S$. rolfsii (mechanism of space competition in the treatment ST3).

The other mechanism of action of indigenous Trichoderma isolates in inhibiting pathogens was antibiosis. The mechanism of antibiosis was characterized by the formation of a clear zone between

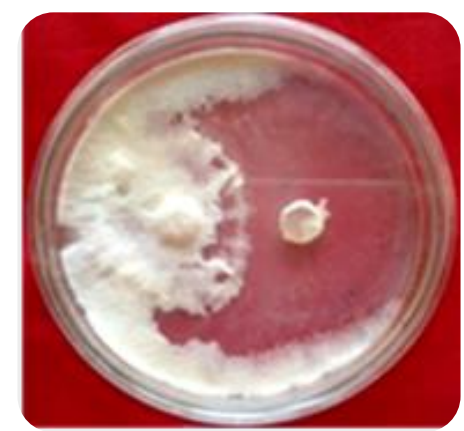

the contact of the Trichoderma colony and that of $S$. rolfsii. This mechanism was seen in the treatments of ST4 and ST8, where hyphal growths from S. rolfsii were present near or adjacent to the hypha or colony of Trichoderma isolates became lysis (hyphae thinning and hyphae were fading or less white) and the presence of clear zones so that it cannot be overgrown by $S$. rolfii hyphae (Figure 3).

Purwantisari and Hastuti (2009) stated that the mechanism of inhibition that occurs in antagonistic tests through the mechanism of antibiosis was characterized by the formation of a clear zone as a zone of inhibition for pathogens. According to Herliyana et al. (2013), the formation of inhibitory zones between microorganisms on solid media was an indication of the working mechanism of antibiosis.

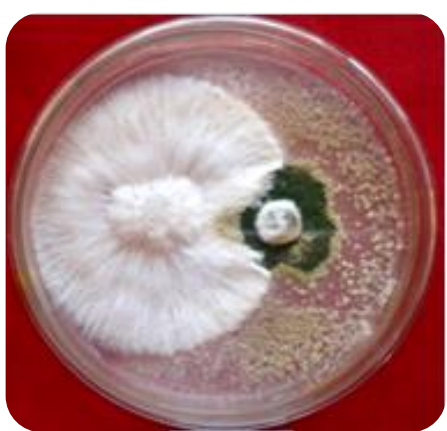

Figure 3. Mechanisms of inhibition by antibiosis by indigenous Trichoderma isolates against S. Rolfsii. a: ST4 (ASL) and b: ST8 (LKP).

Similarly, Berlian et al. (2013) stated that antibiosis was an antagonistic mechanism involving metabolites that caused lysis, enzymes, volatile and non-volatile compounds, or toxins produced by a microorganism. Secondary metabolites produced by Trichoderma spp. also played an important role in its anti-fungal activities. The effectiveness of the mechanism of antibiosis was evidenced by the suppression of the growth of pathogenic fungi on solid media. Trichoderma spp. penetrate the host cell walls with the help of cell wall degrading enzymes viz. chitinase, glucanase, protease, and then use the contents of the host hyphae as a food source. Hallmann (2001) argued that enzymes that act on the mechanism of antibiosis occur due to direct contact with pathogens so that pathogenic hyphae that surround the colony of antagonistic microorganisms may have lysis or the formation of clear zones which form a barrier between the two. According to Mukarlina and Rianti (2010), Trichoderma can produce various types of antibiotics so that it can suppress or inhibit the growth of pathogens. Likewise, Khokhar et al. (2012) found that antagonistic microorganisms can produce various antibiotic compounds that were effective in suppressing the growth of pathogens such as Trichoderma virens produced gliotoxins which suppressed the growth of Rhizoctonia solani.

\section{CONCLUSION}

Trichoderma spp. indigenous to Southeast Sulawesi has different potential and mechanisms to inhibit Sclerotium rolfsi in vitro. DKT isolate of Trichoderma sp. showed the highest inhibitory potential by the inhibition mechanism of space competition and mycoparasitism.

\section{AUTHOR CONTRIBUTION}

All the authors contributed equally in designing the study, execution of the experimental work, collection and analysis of data, manuscript write up and in editing 
and refining the manuscript.

\section{CONFLICT OF INTEREST}

The authors declare no conflict of interest.

\section{ACKNOWLEDGMENT}

We gratefully thank the Ministry of Research Technology and Higher Education for financial support.

\section{REFERENCES}

Berlian, I., Setyawan, B., Hadi, H., 2013. Mekanisme antagonisme Trichoderma spp. terhadap beberapa patogen tular tanah. Warta Perkaretan 32, 74-82.

Ferreira, S.A., Boley, R.A., 1992. Sclerotium rolfsii. Extension Plant Pathologist. Department of Plant Pathology, CTAHR. University of Hawaii at Manoa.

Gusnawaty, H.S., Asniah, M., Taufik, D., 2013. Uji potensi Trichoderma indigenus Sulawesi Tenggara sebagai biofungisida terhadap Phytophthora capsici secara in vitro. Jurnal Agroteknos 3, 139-143.

Gusnawaty, H.S., Taufik, M., Asniah, Bande, L.O.S.B., Faulika, 2015. Potential test Trichoderma indegenus Southeast Sulawesi as to Fusarium oxysporum biofungisida the in-vitro, Proceeding International Conference on Life Science and Biotechnology, Jurusan Biologi, Fakultas Matematika dan Ilmu Pengetahuan Alam. Universitas Jember.

Gusnawaty, H.S., Taufik, M., Bande, L.O.S., Satrah, V.N., Nurmas, A., Mariadi, S., Putri, N.P., Akmal, M., 2020a. The Effectiveness of Bokhasi Biodecomposer and Dosage of Inorganic Fertilizer on Growth and Disease Incidence of Virus Symptom of Soybean. Global Journal of Engineering Science and Researches 7, 21-30.

Gusnawaty, H.S., Taufik, M., Bande, L.O.S., Satrah, V.N., Putri, N.P., Mariadi, Rhaman, A., Asniah, 2020b. Potential of dosage of Bokhasi from Agricultural Waste and Bio-decomposer Trichoderma asperellum on Growth of Three Varieties of Soybean, and Disease Incidence of Stem Rot Caused by Sclerotium rolsfii. IOSR Journal of Agriculture and Veterinary Science 13, 42-50.

Gusnawaty, H.S., Taufik, M., Herman, H., 2014b. Efektifitas Trichoderma Indigenus Sulawesi Tenggara Sebagai Biofungisida Terhadap Colletotrichum Sp. Secara in-Vitro. Jurnal Agroteknos 4, 38-43.

Gusnawaty, H.S., Taufik, M., Triana, L., Asniah, d., 2014a. Karakterisasi Morfologis Trichoderma Spp. Indigenus Sulawesi Tenggara. Jurnal Agroteknos

\section{4, 88-94.}

Hallmann, J., 2001. Plant interactions with endophytic bacteria, in: Jeger, M.J., Spence, N.J. (Eds.), Biotic Interactions in Plant-Pathogen Associations. CABI Publishing, New York, pp. 87-119.

Herliyana, E.N., Jamilah, R., Taniwiryono, D., Firmansyah, M.A., 2013. uji in-vitro pengendalian hayati oleh Trichoderma spp. terhadap Ganoderma yang Menyerang Sengon. Jurnal Silvikultur Tropika 4, 190-195.

Iqbal, U., Mukhtar, T., 2014. Morphological and pathogenic variability among Macrophomina phaseolina isolates associated with mungbean (Vigna radiata L.) Wilczek from Pakistan. The Scientific World Journal. Article ID 950175, 9 pages. https://doi. org/10.1155/2014/950175

Iqbal, U., Mukhtar, T., 2020a. Inhibitory effects of some fungicides against Macrophomina phaseolina causing charcoal rot. Pakistan Journal of Zoology 52, 709-715.

Iqbal, U., Mukhtar, T., 2020b. Evaluation of biocontrol potential of seven indigenous Trichoderma species against charcoal rot causing fungus, Macrophomina phaseolina. Gesunde Pflanzen 72, 195-202.

Iqbal, U., Mukhtar, T., Sheikh, M.I., 2014. In vitro and in vivo evaluation of antifungal activities of some antagonistic plants against charcoal rot causing fungus Macrophomina phaseolina. Pakistan Journal of Agricultural Sciences 51, 691-697.

Ismail, N., Tenrirawe, A., 2010. Potensi Agens Hayati Trichoderma spp, Sebagai Agens Pengendali Hayati. Seminar Regional Inovasi Teknologi Pertanian, mendukung Program Pembangunan Pertanian. Propinsi Sulawesi Utara, pp. 177-189.

Khokhar, M.K., Gupta, R., Sharma, R., 2012. Biological control of plant pathogens using biotechnological aspects: A Review Open Access Scientific Reports, 1:277. doi:210.4172/scientificreports.4277.

Mukarlina, S.K., Rianti, R., 2010. Uji Antagonis Trichoderma harzianum Terhadap Fusarium spp. Penyebab Penyakit Layu pada Tanaman Cabai (Capsicum annum) Secara. Vitro Jurnal Fitomedika 7, 80-85.

Mukhtar, T., 2018. Management of root-knot nematode, Meloidogyne incognita, in tomato with two Trichoderma species. Pakistan Journal of Zoology 50, 1589-1592. 
Octriana, L., 2016. Potensi agen hayati dalam menghambat pertumbuhan Phytium sp. secara in vitro. Buletin Plasma Nutfah 17, 138-142.

Prayudi, B., Budiman, A., Rystham, M.A.T., Rina, Y., 2005. Trichoderma harzianum Isolat Kalimantan Selatan : Agens pengendali hawar pelepah daun padi dan layu semai kedelai di lahan pasang surut, Prosiding Seminar Nasional Hasil-Hasil Penelitian dan Pengkajian Spesifik Lokasi, Pasek, pp. 138142.

Purwantisari, S., Hastuti, R.B., 2009. Uji antagonisme jamur Phytophthora infestans penyebab penyakit busuk daun dan umbi kentang dengan menggunakan Trichoderma spp. isolat lokal. Jurnal Bioma 11, 24-32.

Ropalia, 2017. Potensi endofitn akar bamboo sebagai biokontrol patogen Fusarium oxysporum penyakit kuning tanaman lada. Jurnal Agroscientic 1, 80-85.

Sudanta, I.M., Kesratarta, I., Sudana, 2011. Uji antagonisme beberapa jenis jamur saprofit terhadap jamur Fusarium oxysporum f. sp. cubense penyebab penyakit layu pada tanaman pisang serta potensinya sebagai agens pengurai serasah. Jurnal Agroteksos 21, 2-3.

Sunarwati, D., Yoza, R., 2010. Kemampuan Trichoderma dan Penicillium dalam menghambat pertumbuhan cendawan penyebab penyakit busuk akar durian (Phytophthora palmivora) secara in-vitro, Prosiding Seminar Nasional Program dan Strategi Pengembangan Buah Nusantara, Balitbu Tropika. Solok, pp. 138-142.

Supriati, L., Mulyani, R.B., Lambang, Y., 2010. Kemampuan antagonisme beberapa isolat Trichoderma sp indigenus terhadap Sclerotium rolfsiii secara in-vitro. Jurnal Agroscientic 17, 119122.

Winarsih, S., Syafrudin-dan, 2001. Pengaruh pemberian Trichoderma viridae dan sekam padi terhadap penyakit rebah kecambah di pesemaian cabai. Jurnal Ilmu-Ilmu Pertanian 3, 49-55. 